ISSN 1112-9867

A vailable online at

http://www.jfas.info

\title{
QUANTITATIVE COMPARISON OF AMMONIA AND 3-INDOLEACETIC ACID PRODUCTION IN HALOPHILIC, ALKALOPHILIC AND HALOALKALOPHILIC BACTERIAL ISOLATES IN SOIL
}

\author{
M. E. Torbaghan ${ }^{1, *}$, A. Lakzian $^{1}$, A. R. Astaraei ${ }^{1}$, A. Fotovat $^{1}$ and H. Besharati ${ }^{2}$ \\ ${ }^{1}$ Department of Soil Science, Faculty of Agriculture, Ferdowsi University of Mashhad, Iran \\ ${ }^{2}$ Soil and Water Institute, Agricultural Research, Education and Extension Organization, \\ Karaj, Iran
}

Published online: 13 June 2016

\begin{abstract}
In order to measure the concentration of ammonia production via corrected Nesslerization method and 3-indoleacetic acid as Salkowski method in halophilic, alkalophilic and haloalkalophilic bacterial isolates, soil samples were collected from six different areas of Khorasan Razavi and bacterial isolates isolated and purified using different growth medium accordingly. The alkalophiles isolates showed maximum ammonia production $(0.055 \%)$ among the three groups of bacteria which this amount was 9.5 times of its average in haloalkalophiles isolates $(0.0058 \%)$ and 13 times of ammonia production average in halophiles $(0.004 \%)$. Mean comparison of the concentration3-indoleacetic acid production in three groups also showed that the most isolates of halophiles, alkalophiles and haloalkalophiles were IAA producer with $0.0003,0.0001$ and 0.0021 percent respectively that the IAA amount in haloalkalophilic group was about 6 and 14.5 times of it in halophilic and alkalophilic isolates respectively.
\end{abstract}

Author Correspondence, e-mail: mehrnoosh.eskandary@gmail.com doi: http://dx.doi.org/10.4314/jfas.8vi2s.80 
Equations to predict the concentration of ammonia and 3-indole acetic acid production was only significant in the haloalkalophilic isolates for ammonia production $(\mathrm{P}=0.046)$ and halophilic isolates for IAA production $(\mathrm{P}=0.015)$ under effect of electrical conductivity and $\mathrm{pH}$ in 0.05 probability level. Results represented that the multiple regression analysis for prediction of ammonia and IAA concentrations producing by isolates had not any significant performance in high and low concentrations under effect of electrical conductivity and $\mathrm{pH}$. It seems that the uses of the two sensitive measuring methods (Nesslerization and Salkowski) after some modifications show promises and are recommend able in research due to their ease of implementation and relatively accurate results.

Keywords: Alkalophiles; haloalkalophiles; halophiles; 3-indoleacetic acid; nesslerization method; salkowski method.

\section{INTRODUCTION}

Halophile microorganisms are a group of soil microorganisms that can be grown in the habitats with high salt concentration and have been adapted to these conditions (Zanjirband et al., 2013).Alkalophilic bacteria retain their internal $\mathrm{pH}$ about 9.5 and the external $\mathrm{pH}$ between 9 and 11. These bacteria keep their activities with plasma membrane proton pump in their cytoplasmic membrane (ATP and sodium- proton exchange pump) (Horikoshi, 1999). Another group of bacteria that can grow in the alkaline conditions and in the presence of salt is known as Haloalkalophiles. This dual haloalkalophile characteristic making them interesting for basic studies of different aspects of biotechnology (Joshi, 2006 and Feng et al., 2005). Isolation of these bacteria carries out from habitats such as alkaline lakes, Saltern Lakes, salt brines, carbonate springs and sea salt and alsofrom common saline and alkaline environments such as saline and alkaline soil (Singh et al., 2010).

On the other hand agricultural production was affected by soil salinity and the negative impact of salt on plants interfere on the important biochemical processes of plants by water shortages, osmotic stress and the sodium toxicity(Detkova and Boltyanskaya, 2007).In response to the salinity stress, plants begin to accumulate osmotic regulation compounds with low molecular weight such as sugar alcohols and amino acids. The accumulation of these compounds is a primary mechanism of salt tolerance and adaptation to drought stress in plants. However, in some cases, the amount of osmotic regulator is inadequate. Thus, bacterial osmotic regulator can be used in plants (Rontein et al., 2002).Glycine betaine simulates plant growth and nitrogen fixation under the salinity stress condition In 
Azospirillum haloperfrans and Azospirillum brasilense (Hartman, 1988).These bacteria can improve the resistance of wheat to salinity via nitrogen fixation and hormones producing such as auxin (Saatovich, 2006).Usage of four genera of bacteria and two genera of actinomycete snonsymbiotic diazotrophs haloalkalophiles on wheat (Triticum aestivum L.) showed that plant dry weight was higher in the actinomycetes treatments than the bacteria genus. But the plants height in the bacteria treatments was higher (Butale et al., 2010).

Oren et al. (1991) reported that Halo bacterium parevalens analyzed the maximum of nitrogen-containing aromatic compounds in the salinity condition between 13 and 14 percent. In a study of effect of salinity on the life of free-living diazotrophs and the total population of bacteria in two saline soils (Moradi et al., 2011) was observed that the free-living diazotrophs population and the total heterotrophic bacteria in the soil with $35 \mathrm{dS} / \mathrm{m}$ EC was significantly higher than in the soil with70dS/m EC (Moradi et al., 2011).

It has been reported that IAA produced by bacterial strains isolated from extreme environments helps to plants for salinity tolerance increasing after inoculation of bacteria into the plant (Mishra et al., 2015).Results of determination of various combinations of auxin in 50 strains of P. fluorescens and P. putida species by using HPLC showed that 36 strains (72\%) of bacteria were able to secreteat least one of the auxin indole compounds, including IAA (indole acetic acid), IAM (indole acetamide) and ILA (indole-lactic acid )(Khakipour et al., 2012).Effect of inoculation of bacteria producing IAA on the growth of canola seedlings in the greenhouse experiment also showed that these strains have significantly increased shoot height (up to 15.5\%), shoot dry weight (up 58\%) and root dry weight (up to 305\%) (Khakipour et al., 2012).

Study of bacterial populations in the very salty lake in India (Sambhar) resulted in 93 haloalkalophilic bacterial isolated that had been have optimum growth in an environment of 2-25\% and 6-12 pH (Sahay et al.,2012). In the PGPA parameters ammonium producer with $56 \%$ isolates were maximum compare with ACC-deaminase producer (53\%), IAA (50\%), HCN (28\%), siderophore (21\%), and soluble phosphorous (34\%).Isolates showed plant growth promoting activities and enzymatic producer characteristic that it can be utilized for plant growth improvement in saline area (Sahay et al.,2012).Iran has various saline environments that their microbial diversity, the ability of external hydrolytic enzymes producing, osmotic solutes and even more of these aspects have PGPR characteristics in the agricultural biotechnology studies has been less studied (Rohban et al.,2009). 
This study focused on qualitative identification of ammonium production and 3-indoleacetic acid production in some indigenous extremophile isolates (halophile alkalophile and halo alkalophile) in the Khorasan Razavi Province that have been collected, isolated and purificated from different sources of soil if having this ability the possibility of their usage to fight with salinity stress in the vicinity of the plant is evaluated as the next step.

\section{MATERIALS AND METHODS}

In order to quantitative determination of ammonia and 3-indolacetic acid production by halophilic, alkalpphilic and haloalkalophilic isolates, soil sampling was carried out from six different areas from a depth of 0-25 cm from Khorasan Razavi saline soils (Table 1). Then samples were transferred to the lab in the sterile tubes with area recording by GPS in the time duration less than 48 hours. The samples were kept at $4{ }^{\circ} \mathrm{C}$ during this interval and then were stored at $4^{\circ} \mathrm{C}$ in the lab. Isolation and purification of each halophilic, alkalophilic and haloalkalophilic isolates was done by their specific medium culture (Table 2) from soil samples. For isolation, a 1:1 suspension of soil to water (one gram of soil to one $\mathrm{ml}$ of sterile distilled water) was prepared. One drop of this suspension was spread on the specific agar medium culture. Medium cultures were incubated in the proper temperature ( 35 to $37^{\circ} \mathrm{C}$ ) for 3 to 7 days depending on the type of microorganisms. Fifteen halophilic isolates by Ventosaet al. (1982) medium, nineteen alkalophilic isolates by Horikoshi (I) (2006) and fourteen haloalkalophilic isolates by a specific medium culture (Jones et al, 1992) were isolated respectively. After isolation, subculture was done several times to ensure purity of them. Purified isolates were preserved as a liquid nitrogen method for long time preservation (Horikoshi, 1999).

In order to quantitative measurement of ammonia production, the modified Nesslerization method (Heonsang et al., 2013) with some changes was used to proper it for intended isolates. At the beginning, the specific liquid medium culture was prepared for each group of isolates and the isolated in each group was subcultured again. Then, $20 \mathrm{ml}$ of fresh medium culture from each isolates was centrifuged at $2000 \times \mathrm{g}$ for 10 minutes in the three replicates. $10 \mathrm{ml}$ of centrifuged culture supernatant were transferred to $25 \mathrm{ml}$ balon joje and were increased to the final volume with sterile distilled water. The intended standards were also prepared from $\mathrm{NH} 4 \mathrm{Cl}$ stock solution with $1000 \mathrm{mg}$ concentration. The prepared standard concentration from $\mathrm{NH} 4 \mathrm{Cl}$ was concluded 0, 10, 20 and $40 \mathrm{mg} \mathrm{1-1.} \mathrm{Then,} 0.2$ EDTA was added to all standards, control and samples to eliminate calcium and magnesium ionic interference (Yuen and 
Pollard, 1952). Consumable EDTA was made from dissolving $10 \mathrm{~g} \mathrm{NaOH}$ in $60 \mathrm{ml}$ of twice distilled water via heating and adding $50 \mathrm{~g}$ EDTA and preparing the final volume to $100 \mathrm{ml}$. $0.4 \mathrm{ml}$ of Nessler reagent that was prepared from Fulka company was added to all standards, control and samples and finally the ammonia concentration was read at $420 \mathrm{~nm}$ wave length by spectrophotometry system (PG 9000 model) after 30 minute. After standard curves plotting, the ammonia concentration was determined for each group of isolates.

In order to measurement of 3-indolacetic acid production in the isolates and their replicates, the modified Salkowski method (Glickmann and Dessaux, 1995; Gutierrez et al., 2009) with some changes was used to proper it for intended isolates. At the beginning, the specific liquid medium culture was prepared for each group of isolates and the isolated in each group was subcultured again. In order to IAA determination, $1 \mathrm{~g} \mathrm{~L}$-1 1 f tryptophan amino acid was added to fresh medium culture as a precursor (Swain et al., 2007).Medium cultures were incubated in the proper temperature $\left(35\right.$ to $\left.37^{\circ} \mathrm{C}\right)$ for 3 to 7 days depending on the type of microorganisms. Then medium cultures were centrifuged at $6000 \times \mathrm{g}$ for 10 minutes. To $2 \mathrm{ml}$ of supernatant centrifuged solution was added $2 \mathrm{ml}$ of R1 reagent (Salkowski regent) and next samples were read after $30 \mathrm{~min}$ in the water bath with $32^{\circ} \mathrm{C}$ temperature in the $535 \mathrm{~nm}$ wave length by spectrophotometry system. R1 reagent or Salkowski regent was prepared by $12 \mathrm{~g}$ dissolution of $\mathrm{FeCl} 3.6 \mathrm{H} 2 \mathrm{O}$ in $429 \mathrm{ml}$ sulfuric acid increasing the final volume to 1 liter. To standards preparation at first $100 \mathrm{mg} \mathrm{1-1} \mathrm{stock} \mathrm{solution} \mathrm{was} \mathrm{madeby} \mathrm{dissolution} \mathrm{of} 0.1 \mathrm{~g} 3$ indolaceticacid (Sigma) in 1 liter distilled water and next the other standards $(25,50$ and 75 mg 1-1) were prepared.

Electrical conductivity and $\mathrm{pH}$ were measured in each group of isolates with conductivity and pH meter (EW-35414-00). Osmotic pressure, total dissolved solids and sum of cations or anions was calculated for all isolates (Tables 3 to 5). The ammonia and IAA production by isolates were analyzed using the software MSTAT-C and mean comparison of data was compared by Multiple Dunkan Test in 5\% level. Also, multiple regression analysis calculation was done by MSTAT-C software to study of the effect of $\mathrm{pH}$ and electrical conductivity on ammonia and IAA production in the isolates. 
Table 1. Geographic data of sampled locations of khorasan Razavi

\begin{tabular}{|c|c|c|c|c|c|c|c|c|}
\hline \multirow{2}{*}{ No. } & \multirow{2}{*}{$\begin{array}{l}\text { Location of } \\
\text { sampling }\end{array}$} & \multicolumn{5}{|c|}{ Geografic coordinate of sampling } & \multirow{2}{*}{$\begin{array}{l}\text { Height } \\
\text { (m) }\end{array}$} & \multirow{2}{*}{$\begin{array}{c}\text { Number } \\
\text { of } \\
\text { sample }\end{array}$} \\
\hline & & Second & $\mathrm{Mi}$ & & Degree & Aspect & & \\
\hline \multirow{2}{*}{1} & \multirow{2}{*}{ Bardaskan saltern } & 47 & 36 & 03 & 35 & $N^{\prime}$ & 859 & 2 \\
\hline & & 60 & 08 & 53 & 57 & $\mathrm{E}^{\triangle}$ & & \\
\hline \multirow{3}{*}{2} & Kale shour Aref & 89 & 51 & 5 & 35 & $\mathrm{~N}$ & 933 & 1 \\
\hline & Abad Kashmar & 78 & 37 & 38 & 58 & $\mathrm{E}$ & & \\
\hline & Tounis and & 30 & 50 & 47 & 35 & $\mathrm{~N}$ & 798 & 1 \\
\hline \multirow[t]{2}{*}{3} & $\begin{array}{c}\text { Merendiz of } \\
\text { Bajestan }\end{array}$ & 18 & 22 & 27 & 58 & $\mathrm{E}$ & & \\
\hline & Astan Ghodse & 84 & 33 & 36 & 34 & $\mathrm{~N}$ & 908 & 1 \\
\hline \multirow[t]{2}{*}{4} & $\begin{array}{l}\text { Razavi Gardens- } \\
\text { Gonabad(1) }\end{array}$ & 63 & 56 & 56 & 58 & $\mathrm{E}$ & & \\
\hline & Astan Ghodse & 89 & 30 & 26 & 34 & $\mathrm{~N}$ & 884 & 1 \\
\hline 5 & $\begin{array}{l}\text { Razavi Gardens- } \\
\text { Gonabad(2) }\end{array}$ & 51 & 27 & 58 & 58 & $\mathrm{E}$ & & \\
\hline \multirow{2}{*}{6} & Kale shour Eshgh & 276 & - & 05 & 36 & $\mathrm{~N}$ & 1105 & 1 \\
\hline & Abad Nayshabour & 643 & - & 41 & 58 & $\mathrm{E}$ & & \\
\hline
\end{tabular}

Table 2. Specific media culture of halophilic, alkalophilic and haloalkalophilic bacterial isolates

\begin{tabular}{lccc}
\hline \multirow{2}{*}{ Compounds } & \multicolumn{3}{c}{ Amount (g/L) } \\
\cline { 2 - 4 } & Halophile & Alkalophile & Haloalkalophile \\
\hline Glucose & 1 & 10 & - \\
Poly Peptone & - & 5 & - \\
Yeast extract & 10 & 5 & 10 \\
Di potassium hydrogen phosphate & - & 1 & - \\
Magnesium sulphate seven $\mathrm{H}_{2} \mathrm{O}$ & 9.6 & 0.2 & 1 \\
Sodium carbonate & - & $10^{*}$ & $18.5^{\mathbf{\Delta}}$ \\
Sodium Chloride & 81 & - & 200 \\
Magnesium chloride two $\mathrm{H}_{2} \mathrm{O}$ & 7 & - & -
\end{tabular}


Calcium chloride

Potassium chloride

Sodium hydrogen bicarbonate

Sodium bromide

Protease Peptone

Casino acid

Tri sodium citrate

Manganese(II) chloride

Ferrous sulfate

Agar

$$
0.36
$$

2

$$
0.06
$$$$
0.026
$$

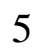

$\begin{array}{ccc}- & - & 7.5 \\ - & - & 3 \\ - & - & 0.00036 \\ - & - & 0.05 \\ 15 & 20 & 20\end{array}$

-pH was adjusted with $\mathrm{KOH} 1 \mathrm{~N}$ on 2.7 before the medium culture sterilization

${ }^{\Delta}$ Was sterile from other materials separately and was added to culture medium before isolates cultivation

Table 3. The amount of $\mathrm{pH}, \mathrm{EC}$, osmotic potential, total dissolved solids and concentration in the halophilic isolates medium in the lag phase

\begin{tabular}{cccccc}
\hline $\begin{array}{c}\text { Isolates } \\
\text { No. }\end{array}$ & $\mathrm{pH}$ & $\mathrm{EC}(\mathrm{dS} / \mathrm{m})$ & O.P $(\mathrm{bar})$ & T.D.S $(\%)$ & $\mathrm{C}(\mathrm{meq} / \mathrm{l})$ \\
\hline H1 & 5 & 43.57 & 15.68 & 2.78 & 435.70 \\
H2 & 5 & 42.45 & 15.28 & 2.71 & 424.53 \\
H3 & 7.6 & 54.74 & 19.70 & 3.50 & 547.42 \\
H4 & 7.3 & 53.62 & 19.30 & 3.43 & 536.25 \\
H5 & 8 & 61.44 & 22.12 & 3.93 & 614.46 \\
H6 & 8.2 & 68.14 & 24.53 & 4.36 & 681.49 \\
H7 & 8.1 & 66.47 & 23.93 & 4.25 & 664.73 \\
H8 & 7.6 & 76.03 & 24.13 & 4.29 & 670.32 \\
H9 & 6.7 & 60.32 & 21.71 & 3.86 & 603.28 \\
H10 & 4.9 & 64.79 & 23.33 & 4.14 & 647.97 \\
H11 & 7.5 & 66.47 & 23.93 & 4.25 & 664.73 \\
H12 & 7.4 & 65.91 & 23.72 & 4.21 & 659.14 \\
H13 & 5.1 & 67.03 & 24.13 & 4.29 & 670.32 \\
H14 & 4.9 & 64.79 & 23.32 & 4.14 & 670.97 \\
H15 & 7.5 & 65.91 & 23.72 & 4.21 & 659.14 \\
Average & 6.72 & 60.85 & 21.90 & 3.89 & 608.50 \\
\hline
\end{tabular}


Table 4. The amount of $\mathrm{pH}, \mathrm{EC}$, osmotic potential, total dissolved solids and concentration in the alkalophilic isolates medium in the lag phase

\begin{tabular}{cccccc}
\hline Strain & pH & EC(dS/m) & O.P (bar) & T.D.S $(\%)$ & C (meq/l) \\
No. & & & & & \\
\hline A1 & 8.85 & 11.96 & 4.30 & 0.7659 & 119.67 \\
A2 & 8.65 & 12.08 & 4.35 & 0.7737 & 120.89 \\
A3 & 9.1 & 12.08 & 4.35 & 0.7737 & 120.89 \\
A4 & 9.05 & 12.21 & 4.39 & 0.7815 & 122.11 \\
A5 & 9.1 & 12.33 & 4.44 & 0.7893 & 123.33 \\
A6 & 8.85 & 12.21 & 4.39 & 0.7815 & 122.11 \\
A7 & 9 & 12.33 & 4.44 & 0.7893 & 123.33 \\
A8 & 8.8 & 12.69 & 4.57 & 0.8127 & 127 \\
A9 & 7.5 & 11.47 & 4.13 & 0.7346 & 114.78 \\
A10 & 9.1 & 11.47 & 4.13 & 0.7346 & 114.78 \\
A11 & 9 & 12.21 & 4.39 & 0.7815 & 122.11 \\
A12 & 9.1 & 12.45 & 4.48 & 0.7917 & 124.55 \\
A13 & 9.1 & 12.21 & 4.39 & 0.7815 & 122.11 \\
A14 & 9.1 & 12.21 & 4.39 & 0.7815 & 122.11 \\
A15 & 9 & 12.69 & 4.57 & 0.8127 & 127 \\
A16 & 9 & 12.45 & 4.48 & 0.7971 & 124.55 \\
A17 & 9 & 13.55 & 4.87 & 0.8675 & 135.54 \\
A18 & 9.1 & 12.82 & 4.61 & 0.8206 & 128.22 \\
A19 & 8.8 & 12.33 & 4.44 & 0.7893 & 123.33 \\
Average & 8.89 & 12.21 & 4.39 & 0.7815 & 122.11 \\
\hline & & & & & \\
\hline
\end{tabular}

Table 5. The amount of $\mathrm{pH}$, EC, osmotic potential, total dissolved solids and concentration in the haloalkalophilic isolates medium in the lag phase

\begin{tabular}{cccccc}
\hline $\begin{array}{c}\text { Strain } \\
\text { No. }\end{array}$ & pH & EC(dS/m) & O.P (bar) & T.D.S $(\%)$ & C (meq/l) \\
\hline HA1 & 8.8 & 48.17 & 17.34 & 3.08 & 841.74 \\
HA2 & 8.9 & 68.64 & 24.71 & 4.39 & 686.47 \\
HA3 & 8.7 & 75.87 & 27.31 & 4.85 & 758.74 \\
HA4 & 9 & 86.71 & 31.21 & 5.54 & 867.13
\end{tabular}




\begin{tabular}{cccccc} 
HA5 & 9.2 & 98.75 & 35.55 & 6.32 & 987.56 \\
HA6 & 8.9 & 102.36 & 36.85 & 6.55 & 1023.96 \\
HA7 & 9 & 108.39 & 39.02 & 6.93 & 1091.91 \\
HA8 & 8.9 & 107.18 & 38.58 & 6.85 & 1071.87 \\
HA9 & 9 & 114.41 & 41.18 & 7.32 & 1144.13 \\
HA10 & 9.1 & 295.06 & 106.22 & 18.88 & 2950.65 \\
HA11 & 9.1 & 252.91 & 91.04 & 16.18 & 2529.13 \\
HA12 & 9.1 & 277.00 & 99.72 & 17.72 & 2770.00 \\
HA13 & 8.9 & 264.95 & 95.38 & 16.95 & 2649.57 \\
HA14 & 9 & 252.91 & 91.04 & 16.18 & 2529.13 \\
Average & 8.99 & 159.61 & 57.46 & 10.21 & 1596.16 \\
\hline
\end{tabular}

\section{RESULTS AND DISCUSSION}

Mean comparison of NH3 production in halophilic isolates (Fig. 1) showed that production of NH3had significant difference in different isolates at 5\% level. The range of NH3 production was changeable between 0 to $0.01554 \%$ in the isolates. Maximum and minimum ammonium concentration was observed in $\mathrm{H} 8$ and $\mathrm{H} 9$ isolates respectively.

Maximum of NH3concentration was observed in alkalophilic isolates among the three groups of them (Fig. 2). Maximum of NH3 was observed in A7 and A5 without significant difference together and after them in A16 with significant difference with both of them (Fig 2). Minimum concentration was observed in A18, A12 and A4 without significant difference with each other at 5\% level. Mean comparison of remained isolates did not show any significant difference together (Fig 2).

The concentration of ammonia production in haloalkalophile isolates showed no significant difference together at 5\% statistical level (Fig 3). Generally, Maximum average of ammonia concentration was observed in alkalophile isolates $(0.055 \%)$ that it was 9.5 and 13 times more than that in the haloalkalophiles $(5.797 \times 10-3 \%)$ and halophiles $(3.992 \times 10-3 \%)$ respectively. Some of nitrate-producing bacteria from ammonium are relatively alkalophiles that some of which are relatively aerobic chemo organotroph (such as bacillus) and anaerobic (eg, Clostridium) (Bertrand et al., 2014). Indirect evidence, such as the presence of the active population denitrification bacteria and nitrate consumer bacteria, including $\mathrm{H}$ eterotrophic haloalkaliphilic Halomonas spp. (Sorkin, 2003) and chemolithoautotrophic sulfur oxidizing bacteria showed that nitrogen oxides may be formed in the alkaline environment. Cluster 
culture experiments have shown that isolates in alkaline lake belonging to obligatory alkalophiles with a $\mathrm{pH}$ about 9. In limited continuous culture with ammonia along with control $\mathrm{pH}$, one of the isolates grew at $\mathrm{pH}$ greater than 11.4. Absolute maximum not only among chemo litho autotrophic, but even close to the maximum was established for alkalophiles heterotrophic (11.5) (Sturr et al., 1994). This shows that alkalophiles ammonia producer somehow to overcome the major problem (such as carbon limits) autotrophic metabolism in the extremely high carbonate to bicarbonate ratio. However, high salt concentration was a bigger problem for ANs strains such as Nitrosomonas halophila than to high $\mathrm{pH}$. Growth was possible in the range between 0.1 to $0.9 \mathrm{M}$ sodium from sodium chloride scorce. Cultures did not need to $\mathrm{Cl}^{-}$, They could growth in the pure sodium carbonate culture. The other problem for this special nitrificators was ammonium concentration. They could not tolerate to higher concentration of $8 \mathrm{mM}$ ammonium chloride in $\mathrm{pH}=10$ and they could not grow without lag phase when ammonium concentration was lower than $4 \mathrm{mM}$. Ammonium toxicity increased with pH increase (Sturr et al., 1994).

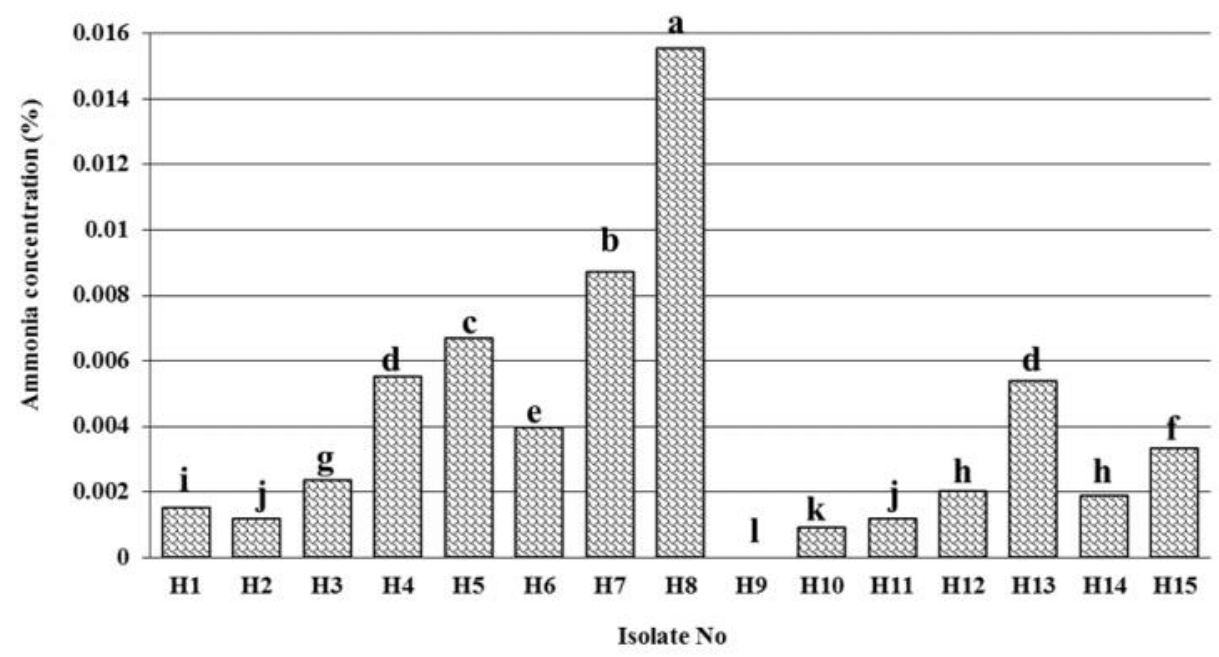

Fig.1. Mean comparison of ammonia concentration in halophilic isolates (\%) 


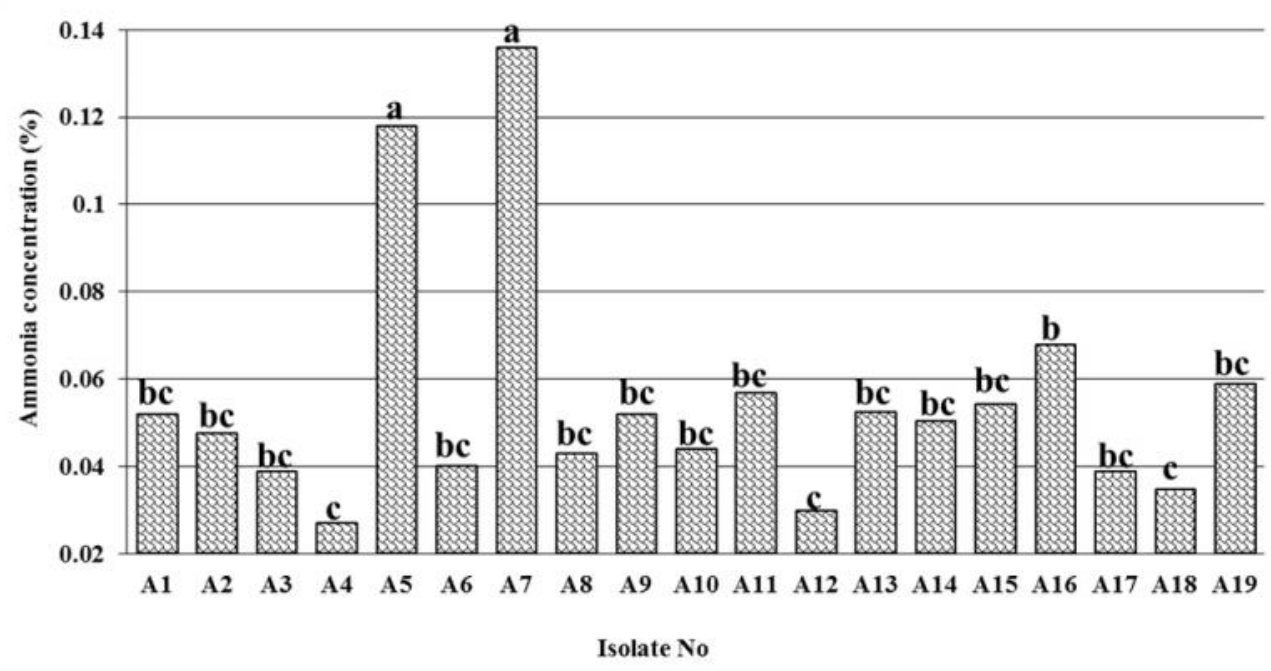

Fig.2. Mean comparison of ammonia concentration in alkalophilic isolates (\%)

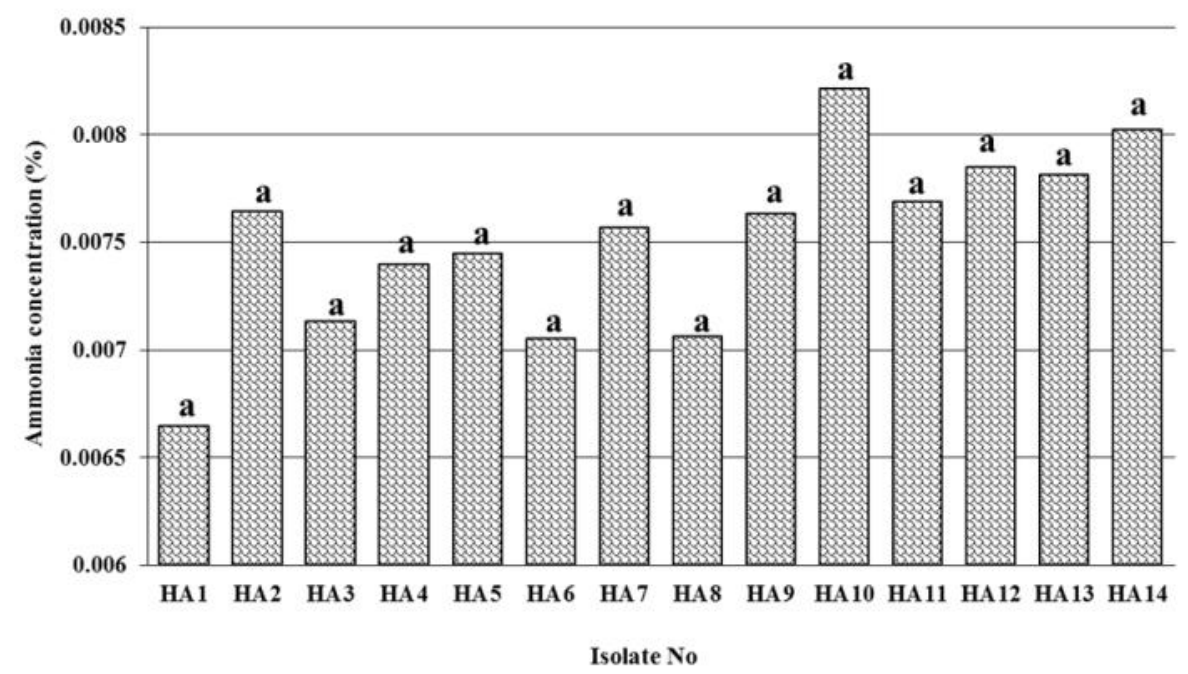

Fig.3. Mean comparison of ammonia concentration in haloalkalophilic isolates (\%)

Results of multiple regression analysis in ammonium concentration for each group of isolates (Table 2) also showed that the only equation of production ammonium concentration forecasting in haloalkalophiles (the third equation of table 6) was significant under effect of electrical conductivity and $\mathrm{pH}$ at $5 \%$ level $(\mathrm{P}=0.046)$. Results of multiple regression analysis were not significant for other equations and regression coefficients statistically (Table 6). 
Table 6. Results of multiple regression analysis for ammonium concentration in halophilic, alkalophilic and haloalkalophilic isolates

\begin{tabular}{|c|c|c|c|c|c|c|c|c|}
\hline & & Regressi & & & & & & \\
\hline $\begin{array}{l}\text { Type of } \\
\text { isolate }\end{array}$ & $\begin{array}{l}\text { Independ } \\
\text { ent } \\
\text { variables }\end{array}$ & $\begin{array}{c}\text { on } \\
\text { Coefficie } \\
\text { nts of } \\
\text { independ } \\
\text { ent } \\
\text { variables }\end{array}$ & $\begin{array}{l}\text { Significa } \\
\text { nt of } \\
\text { independ } \\
\text { ent } \\
\text { variables }\end{array}$ & Equation & $\begin{array}{c}\text { Regressi } \\
\text { on } \\
\text { Coefficie } \\
\text { nts }\left(\mathrm{R}^{2}\right)\end{array}$ & $\begin{array}{c}\text { Adjusted } \\
\text { regressio } \\
n \\
\text { Coefficie } \\
\text { nts }\left(\mathrm{R}^{2}\right. \\
\text { adj })\end{array}$ & $\begin{array}{l}\text { Multiple } \\
\text { Regressi } \\
\text { on } \\
\text { Coefficie } \\
\text { nts }\left(\mathrm{R}^{2}{ }_{\mathrm{M}}\right)\end{array}$ & $\begin{array}{l}\text { Signific } \\
\text { ant of } \\
\text { equation }\end{array}$ \\
\hline Halophile & $\begin{array}{c}\mathrm{EC} \\
(\mathrm{dS} / \mathrm{m}) \\
\mathrm{pH}\end{array}$ & 0.839 & $\begin{array}{l}0.539 \\
0.227\end{array}$ & $\begin{array}{c}\mathrm{NH}_{3}=1.77 \\
\mathrm{EC}- \\
4.65 \mathrm{pH}- \\
83.39\end{array}$ & 0.209 & 0.077 & 0.457 & 0.245 \\
\hline Alkalophile & $\begin{array}{c}\mathrm{EC} \\
(\mathrm{dS} / \mathrm{m}) \\
\mathrm{pH}\end{array}$ & $\begin{array}{c}-4.82 \times 10^{-} \\
3\end{array}$ & 0.771 & $\begin{array}{c}\mathrm{NH}_{3}=2.67 \times \\
10^{-4} \mathrm{EC}- \\
1.38 \times 10^{-4} \\
\mathrm{pH}+0.062\end{array}$ & 0.007 & -0.117 & 0.086 & 0.943 \\
\hline $\begin{array}{l}\text { Halialkalop } \\
\text { hile }\end{array}$ & $\begin{array}{c}\mathrm{EC} \\
(\mathrm{dS} / \mathrm{m})\end{array}$ & $4.25 \times 10^{-2}$ & 0.184 & $\begin{array}{c}\mathrm{NH}_{3}=7.66 \\
\mathrm{EC}- \\
2.58 \mathrm{pH}- \\
180.41\end{array}$ & 0.429 & 0.325 & 0.655 & $0.046^{*}$ \\
\hline
\end{tabular}

* Significant at $5 \%$ level

In many cases, the use of different substrate acts as an important feature in the identification of bacterial species (Hansen, 1930). One of the important factors in the selection of ammonium measurements methods is its concentration and the presence of interfering ions measurements. The minimum ammonium concentration must be more than $20 \mathrm{mg} / \mathrm{L}$ in the Nesslerization method (Hansen, 1930) with regard to mean of ammonium concentration producing by isolate in this method and as well as ease of its, the usage of it seems suitable. The study of twenty endophytic bacteria isolated from four dominant halophyte leaves and species resistant to salt in the Gujarat region of India revealed that six bacteria (30\%) and two bacteria (10\%) were ammonium producer and have mineral phosphorous solubilization activity (Arora et al., 2014).From this bacteria, 85\% of isolates (17 bacteria) grew in $7.5 \%$ 
sodium chloride and 15 bacteria and $75 \%$ of them showed tolerance to more concentration than $10 \%$ of sodium chloride. Phylogenetic analysis showed that the bacteria belonging to the genus Bacillus. Phylogenetic analysis showed that the bacteria belonging to the genus Bacillus (Arora et al., 2014).

The study of IAA in halophilic isolates (Fig. 4) showed that maximum of IAA production was observed in H8, H7, H5 and H6 isolates with significant difference to each other at 5\% level. Results showed H4 isolate was not IAA producer (Fig 4). The range of IAA production among halophilic isolates was variable between 0 to $2.036 \times 10^{-3} \%$.

Results of experiment showed that most of alkalophiles isolates were not IAA producer (Fig 5). Maximum of concentration of IAA production was observed in A8 and A1 with $5.752 \times 10^{-}$ ${ }^{3} \%$ and $3.827 \times 10^{-3} \%$ and significant difference together. After that the two isolates (A11 and A13) had maximum IAA concentration without significant difference to each other and then A7 isolate was observed (Fig. 5).

Maximum and minimum IAA concentration was observed in haloalkalophilic isolates (Fig.6) with $5.083 \times 10^{-3}$ and 0 percent in the HA3 and HA5 isolates respectively. Then, both HA8 and HA9 isolates showed maximum IAA concentration with $4.393 \times 10^{-3}$ and $3.604 \times 10^{-3} \%$ respectively after the maximum concentration with significant difference together in $5 \%$ level (Fig. 6).

Mean comparison of IAA concentration in three groups of isolates showed that haloalkalophilic, halophilic and alkalophilic isolates with average of $2.116 \times 10^{-3} \%, 3.46 \times 10^{-}$ ${ }^{4} \%$ and $1.46 \times 10^{-4} \%$ were IAA producer respectively that IAA production in a haloalkalophilic group was about 6 and 14.5 times more than IAA concentration produced by halophilic and alkalophilic groups.

In a study of 60 rhizobium and pseudomonas fluorescens isolates determined that between rhizobium and pseudomonas fluorescens isolates was observed significant difference in the ability of IAA production and among them R9 isolate with minimum IAA production $(0.45$ ppm) and R32 isolate with maximum ability of IAA production (10.86 ppm) were selected as unable and top isolates (Alikhani et al, 2011).Evaluation of population and growth stimulating properties of endophytic, rhizospheric and non-rhizospheric bacteria in pistachio seedlings under greenhouse conditions showed that the frequency of endophytic, rhizospheric and nonrhizospheric bacteria in the production of indole acetic acid was 48.5, 60 and 47.5 percent respectively and the abundance of isolates in nitrogen-fixing was 27.3, 64 and 17.4 percent respectively (Hojat Noghi et al, 2013). 
Study and isolation of two bacteria Bacillus licheniformis and Bacillus sp. resistance to salinity respectively with 300 and $400 \mathrm{mmol} / \mathrm{L}$ of sodium chloride of potato rhizosphere of a saline soil in Algeria showed that both bacteria producing a lot more-indole acetic acid (78 and 101 milligrams per liter), respectively. These bacteria also produce numerous enzymes such as urease and they have also showed capable of producing siderophore, dissolution of inorganic phosphorous and antifungal properties (Nabti et al., 2013).

Results of multiple regression analysis of IAA concentration for each group of isolates (Table 7) also showed that the only equation for production of IAA concentration forecasting in halophilic isolates (the first equation of table 7) was significant under effect of electrical conductivity and $\mathrm{pH}$ at $5 \%$ level $(\mathrm{P}=0.015)$. Results of multiple regression analysis were not significant for other equations and regression coefficients statistically (Table 7).

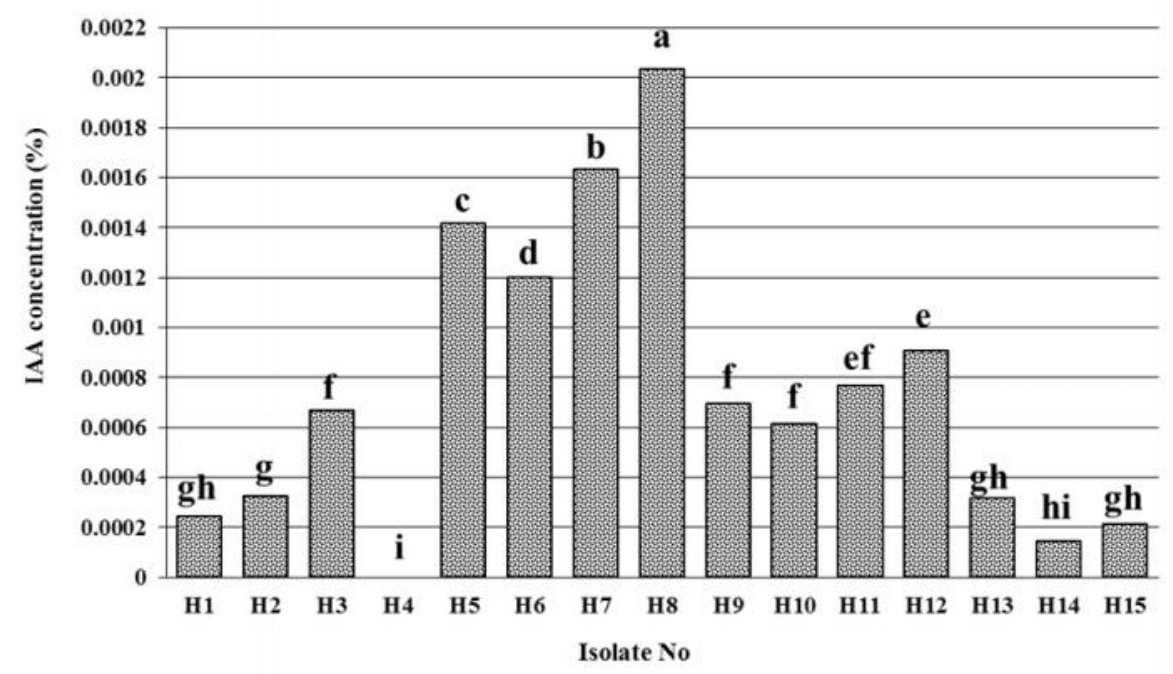

Fig.4. Mean comparison of IAA concentration in halophilic isolates (\%)

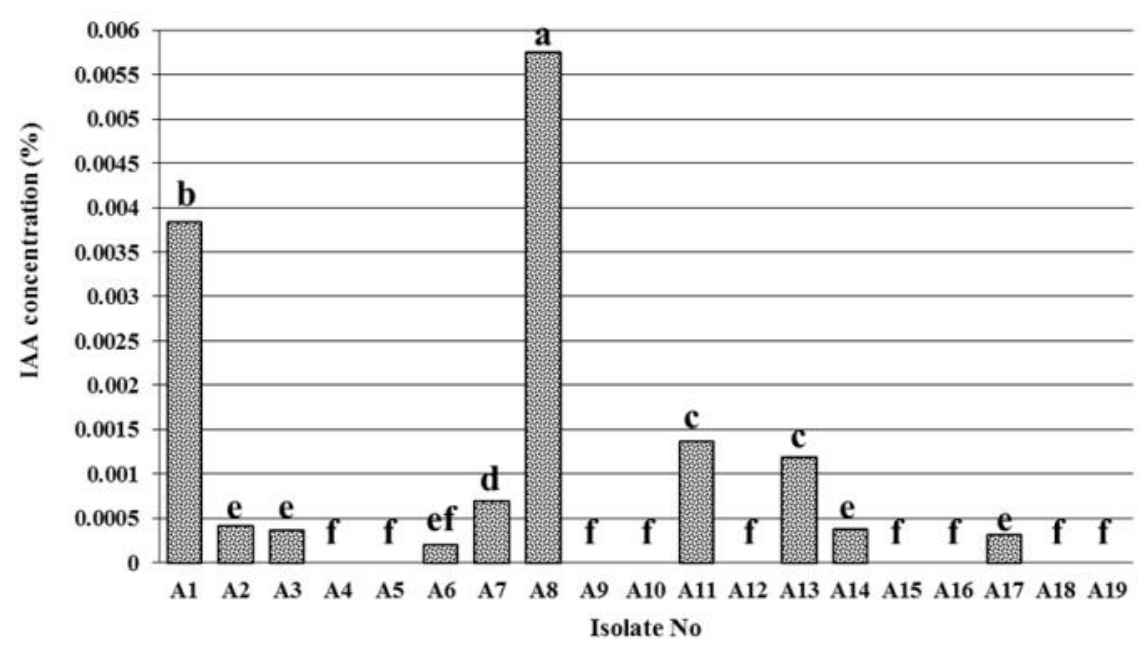

Fig.5. Mean comparison of IAA concentration in alkalophilic isolates (\%) 


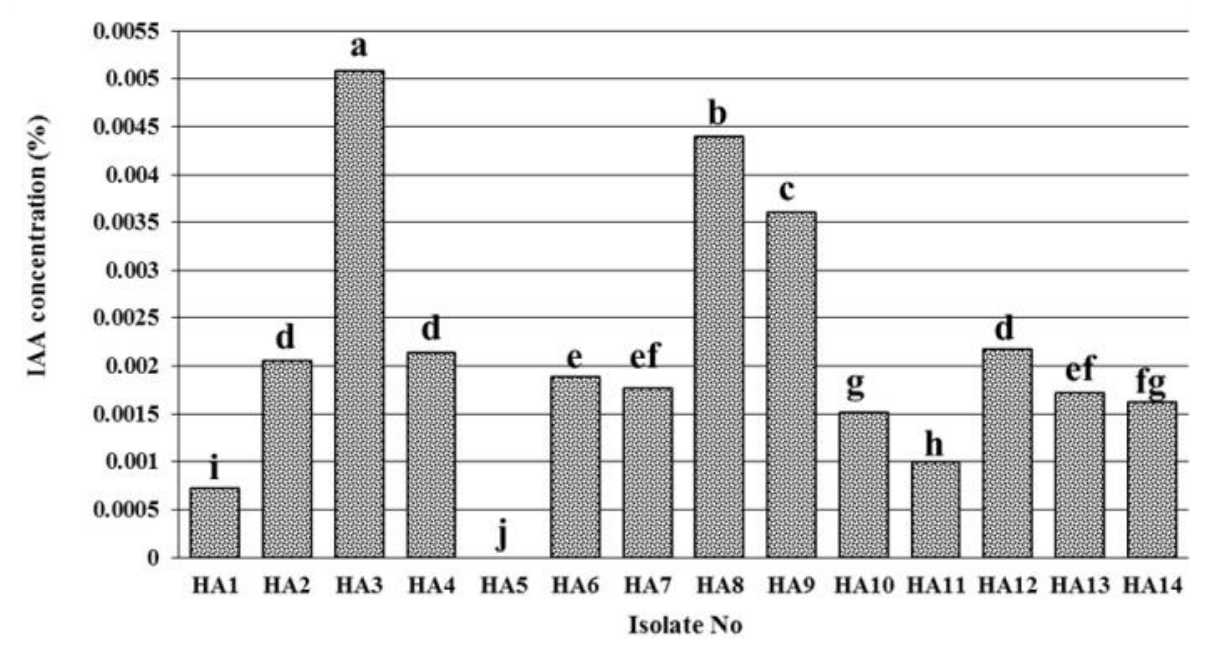

Fig.6. Mean comparison of IAA concentration in haloalkalophilic isolates (\%)

Table 7. Results of multiple regression analysis for IAA concentration in halophilic, alkalophilic and haloalkalophilic isolates

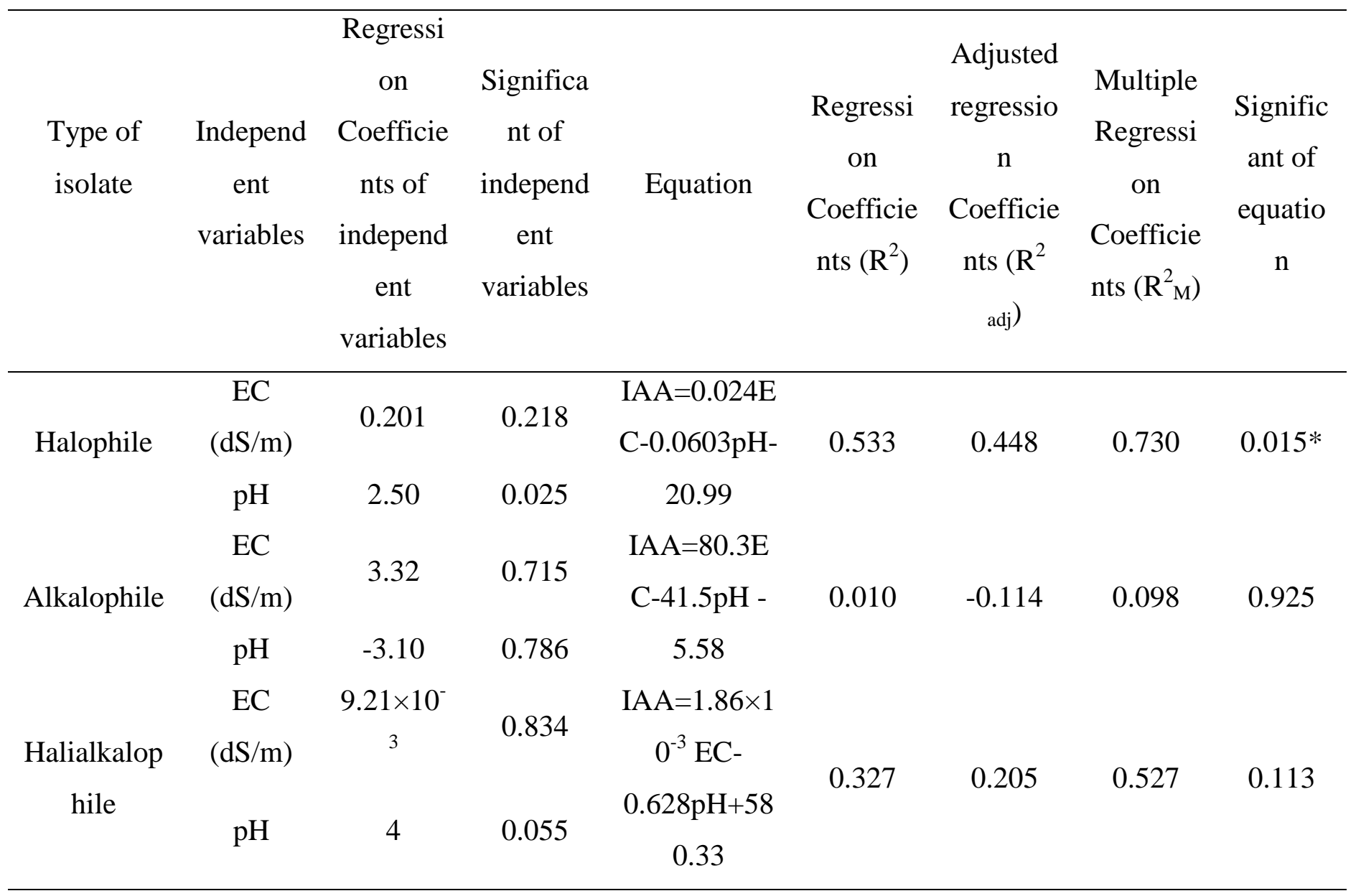


The average of $\mathrm{pH}$ in halophiles isolates was acidic (6.72) (Table 3). The most isolate's growth caused $\mathrm{pH}$ changing in the medium. Maximum and minimum $\mathrm{pH}$ was observed with 4.9 and 8.4 for H10 and H14 (maximum) and H6 (minimum). Growth of six isolates (H10, $\mathrm{H} 14, \mathrm{H} 1, \mathrm{H} 2, \mathrm{H} 13, \mathrm{H} 9)$ cause $\mathrm{pH}$ reduction compare to the primary medium, but, the growth of other isolates caused increasing $\mathrm{pH}$ in the medium culture (Table 3). The average of electrical conductivity was $60.85 \mathrm{dS} / \mathrm{m}$ in the medium (Table 3). The average of osmotic potential, total dissolved solids and concentration was $21.9 \mathrm{bar}, 3.89 \%$ and $608.5 \mathrm{mq} / \mathrm{L}$. High osmotic potential in the bacterial medium culture is about of osmotic potential in soils in the permanent wilting point (10 to $20 \mathrm{~atm}$ ) that it can be a reason for living and performance of this bacteria in the high salinity of soil near to plant according to the other report's researchers (Saatovich, 2006 and Mishra et al., 2015)

Compare the $\mathrm{pH}$ value of the alkalophilic isolates (Table 5) indicated alkaline conditions in the medium culture and changing the $\mathrm{pH}$ of the medium ( $\mathrm{pH}$ was 7.8 in the control).None of the bacteria growth in acidic and neutral $\mathrm{pH}$ range occurred and the $\mathrm{pH}$ value is allocated to the lowest level in A9 isolate (7.5). Alkalophilic bacteria can change the environmental $\mathrm{pH}$ to proper grow (Horikoshi, 2006). Bacillus clausii No. 221 is a good alkaline protease producer. It can be grow in the neutral $\mathrm{pH}$ lowly and change the $\mathrm{pH}$ of liquid culture medium. It was observed that when the acidity of the medium was about 9, bacteria begin to grow fast and produced large amounts of the alkaline protease. Oyama and Horikoshi were isolated an alkalophilc from Arthrobacter sp. so that it exploits the $\varepsilon$-caprolactam polymer. This microorganism can also change the acidity of the liquid medium into a proper acidity (Horikoshi, 2006).

Study of electrical conductivity of isolates also showed that their growth in the medium culture had little effect on medium electrical conductivity. The EC was $10.4 \mathrm{dS} / \mathrm{m}$ in the control. Another distinguishing feature of Bacillus alkalophilic strains is that for many of them sodium ions for growth and mobility is absolutely required. Amino acid uptake into cells as a function of sodium chloride by Kitada and Horikoshi (1977) showed that the presence of sodium chloride plays an important role in the mechanism of active transport of amino acids into alkalophilic cells. In some Bacillus alkalophilic strains, potassium ions $\left(\mathrm{K}^{+}\right)$ can be an alternative to sodium ions (Horikoshi, 2006). Sodium needs has also been observed and confirmed in the process of differentiation, spore production and germination of alkalophilic strains (Horikoshi, 2006). The average of osmotic potential, total dissolved solids and concentration was 4.39 bar, $0.7815 \%$ and $122.11 \mathrm{mq} / \mathrm{L}$ (Table 4). Kodo and Horikoshi 
(1983a) reported the germination of alkalophilic bacillus pseudofirmus. None germination was observed in the absence of sodium chloride. Suitable temperature for germination and sprouting was about $\mathrm{C}^{\circ} 37$ and germination was happened in the range of $\mathrm{pH} 8.5$ to 11.1. $\mathrm{pH}$ suitable for germination was about 10. 1.0 to 5.0 molar concentration of sodium chloride was suitable for germination. Other cations such as potassium, ammonium, rubidium, cesium and calcium did not show this simulating effect. Lithium cation showed only weak stimulus (Kudo and Horikoshi, 1983b).

The average of $\mathrm{pH}$ in haloalkalophilic isolates was 8.99 (table 5) that it had not significant difference with $\mathrm{pH}$ of control (9.13). Mean of electrical conductivity was very high in the haloalkalophilic isolates $(159.61 \mathrm{dS} / \mathrm{m})$. The study of EC amounts in isolates had high difference after growth (Table 5). Maximum and minimum of it was observed for HA1 and HA10 with 48.17 and $259.06 \mathrm{dS} / \mathrm{m}$ respectively. The average of osmotic potential, total dissolved solids and concentration was 57.46 bar, $10.21 \%$ and $1596.16 \mathrm{mq} / \mathrm{L}$ (Table 5). The average of $\mathrm{pH}$ was higher in the alkalophilic isolates than to halophilic group. But the amount of EC, osmotic potential, total dissolved solids and concentration had increasing trend in alkalophilic, halophilic and haloalkalophilic isolates (Table 3, 4 and 5). The amount of EC, osmotic potential, total dissolved solids and concentration in haloalkalophilic isolates was 13 and 2.6 times bigger than alkalophiles and halophiles. These microorganisms to survive in stressful conditions have developed bioenergy and structural adjustment of $\mathrm{pH}$ to maintain homeostasis and intracellular osmotic pressure (2014, .al et Sorokin).

\section{CONCLUSION}

The average ammonia production in alkalophilic isolates $(0.055 \%)$ was much higher than the other two groups. The Nesslerization method is a very sensitive method for measuring low ammonia concentration but even in the medium of Halophiles with the average $\mathrm{pH}$ of 6.72 and ionic interference may cause measuring error, the application of the method with slight variations was satisfactory. The producing IAA concentration was higher in the haloalkalophilic isolates than the two other group and this concentration was not under effect of $\mathrm{pH}$ and electrical conductivity and directly dependent on the type of microorganisms.

\section{REFERENCES}

[1] Alikhani H, Saghafi Marakhanlo D, Ebadi Nahari A. Evaluation of production hormone auxin, indole acetic acid (IAA) by Rhizobium bacteria and Pseudomonas fluorescens. 
The first National Conference on Modern Agricultural Sciences \& Technologies; 2011, Zanjan, University of Zanjan.

[2] Arora S, Patel PN, Vandez MJ, Rao GG.2014.Isolation and characterization of endophytic bacteria colonizing halophyte and other salt tolerant plant species from coastal Gujarat. African Journal of Microbiology Journal 2014, 8 (17):1779-1788.

[3] Bertrand JC, Caumette P, Lebaron P, Matheron R, Normand P, Sime-Ngando T. Environmental Microbiology: Fundamentals and Applications: Microbial Ecology. Germany: Springer; 2014.

[4] Butale SV. Raut AA, Sawant TB. Application of moderately haloalkaliphilic nonsymbiotic diazotrophs of Lonarlake to saline soils.International Journal of Microbiology Research.2010, 2(2), 1-4.

[5] Detkova EN, Boltyanskaya Yu V. Osmoadaptation of Haloalkaliphilic Bacteria: Role of Osmoregulators and Their Possible Practical Application. Microbiology 2007, 76(5): $511-522$.

[6] Feng JP, Zhou Y, Zhou S, Liu Rhodes KW. Halorubrumalkaliphilum sp. nov., a novel haloalkaliphile isolated from a soda lake in Xinjiang, China. International Journal of Systematic Evolutionary Microbiology 2005, 55, 149-152.

[7] Glickmann E, Dessaux Y. A Critical Examination of the Specificity of the Salkowski Reagent for Indolic Compounds Produced by Phytopathogenic Bacteria, Applied and Environmental Microbiology 1995, 61(2), 793-796.

[8] Gutierrez CK, Matsui GY, Lincoln D E, Lovell CR. Production of the Phytohormone Indole-3-Acetic Acid by Estuarine Species of the Genus Vibrio. American Society for Microbiology, 2009, 75(8), 2253-2258.

[9] Hansen PA. The detection of ammonia production by bacteria in agar slants. Journal of Bacteriology, 1930, 19 (3), 223-229.

[10]Hartman A. Ecophysiological aspects of growth and nitrogen fixation in AzospirillumSpp, Plant and Soil 1988, 110, 225-238.

[11]Heonsang J, Jongtaek P, Hyunook K. Determination of NH4+ in Environmental Water with Interfering Substances Using the Modified Nessler Method. Hindawi Publishing Corporation Journal of Chemistry 2013, 1-9.

[12]Hojjat Noughi F, Akhgar AR, Esfandiarpour I, Khavazi K. Evaluation of Population and Properties of PGPB of Endorhizosphere, Rhizosphere and Nonrhizosphere in Pistachio Seedlings.Water and Soil Science 2013, 23 (4), 215-234. 
[13]Horikoshi K, Alkaliphiles. Kodansha: Hardwood Academy Publisher. Germany: Springer, 1999.

[14]Horikoshi K. Alkaliphiles-Genetic Properties and Applications of Enzymes. Japan. Springer, 2006.

[15]Horikoshi K. Alkaliphiles: Some Applications of Their Products for Biotechnology. Microbiology and Molecular Biology Reviews 1999, 735-750.

[16] Jones B, Brian E, Gravin J. Stolberglaan V. European patent application. 1992; Bulletin 93/18. Publication number: EP 0540127 A1. Rank Xerox (UK) Business Services (3. 10/3.6/3.3. 1)

[17] Joshi R. Extracellular Enzymes from halophilic and haloalkaliphilic bacteria isolated from seawater along the coastal Gujarat. Rajkot, India: SaurashtraUniv, 2006.

[18] Khakipour N, Khavazi K, Akhgar A. Identification of Indole compounds produced by a selection of fluorescent Pseudomonas and their inoculation effect on the growth of rape. Iranian Journal of soil Research 2012, (A) 26(4), 415-423.

[19] Kitada M, Horikoshi K. Sodium ion-stimulated a-(1-C)-aminoisobutyric acid uptake in alkalophilicBacillus species. Journal of Bacteriology 1977, 131, 784-788.

[20]Kudo T, and Horikoshi K. RNA-polymerase of alkalophilic Bacillus sp. No.2b-2. The Third International Symposium Ribosomes and Nucleic Acid Metabolism; 1983b; Czechoslovakia; 247-256.

[21]Kudo T, Horikoshi K. RNA Polymerase from vegetative cells and spores of an alkalophilic Bacillus sp. Spores VII, 220. The Third International Symposium Ribosomes and Nucleic Acid Mitabolism; 1983a, Czechoslovakia.

[22] Mishra S, singh RP, Raghuvanshi S, Gupta S. Deducing the Bio-Perspective Capabilities of $\mathrm{Fe}(\mathrm{II})$ Oxidizing Bacterium Isolated from Extreme Environment. Biochemistry \& Analytical Biochemistry 2015; 4, 2, 1-5.

[23] Moradi A, Tahmourespour A, Hoodaji M, Khorsandi F. Effect of salinity on free living diazotroph and total bacterial populations of two saline soils. African Journal of Microbiology Research 2011, 5(2), 144-148.

[24] Nabti EH, Mokrane N, Ghoul M, Manyani H, Dary M, Megias MG. Isolation and Characterization of Two Halophilic Bacillus (B. licheni formis and Bacillus sp.) with Antifungal Activity. Journal of Ecology of Health \& Environment.2013, 1(1), 13-17. 
[25] Oren A, Gurevich P, Henis Y. Reduction of nitro substituted aromatic compounds by the halophilic anaerobic eu-bacteriua Haloanaerobium praevalens and Sporo halo bacter marismortui. Applied and Environmental Microbiology, 1991, 57, 3367-3370.

[26] Rohban R, Amoozegar MA, Ventosa A. Screening and isolation of halophilic bacteria producing extracellular hydrolyses from Howz Soltan Lake, Iran. Journal Industerial Microbiology and Biotechnology 2009, 36, 333-340.

[27]Rontein D, Basset G, Hanson AD. Metabolic Engineering of Osmoprotectant Accumulation in Plants, Metabolic Engineering, 2002, 4, 49-56.

[28] Saatovich SZ. Azospirilli of Uzbekistan soil and their influence on growth and development of wheat plants.Plant and Soil 2006, 283, 137-145.

[29] Sahay H, Mahfooz S, Singh AK, Singh S, Kaushik R, Saxena AK, Arora DK. Exploration and characterization of agriculturally and industrially important haloalkaliphilic bacteria from environmental samples of hypersalineSambhar lake, India. World Journal of Microbiology and Biotechnology 2012, 28, 3207-3217.

[30] Singh SP, Purohit MK, Raval VH, Pandey S, Akbari VG, Rawal CM. Capturing the potential of Haloalkaliphilic bacteria from the saline habitats through culture dependent and metagenomic approaches, Curent Reasearch, Technology and Education Topics in Applied Microbiology and Microbial Biotechnology, 2010, 81-87.

[31] Sorokin DY, Berben T, Denise Melton E, Overmars L, Vavourakis CHD, Muyzer G. Microbial diversity and biogeochemical cycling in soda lakes. Extremophiles, 2014, 18(5), 791-809.

[32] Sorokin DY. Oxidation of inorganic sulfur compounds by obligately organotrophic bacteria. Microbiology (Moscow, English Translation), 2003, 72, 641-653.

[33] Sturr MG, Guffanti AA, Krulwich TA. Growth and bioenergetics of alkaliphilicBacillus firmus OF4 in continuous culture at high pH.Journal of Bacteriology 1994, 176, 31113116.

[34] Swain MR, Naskar SK, Ray RC. Indole-3-acetic acid production and effect on sprouting of yam (Dioscorearotundata L.) minisetts by Bacillus subtilis isolated from culture able cowdung micro flora. Polish Journal of Microbiology 2007, 56(2), 103-110.

[35] Ventosa A. Quesada E, Rodriguez-Valera F, Ruiz-Berraquero F, Ramos-Cormenzana A. Numerical taxonomy of moderately halophilic Gram-negative rods. Journal of general microbiology, 1982, 128, 1959-1968. 
[36] Yuen SH, Pollard AG. The determination of nitrogen in agricultural materials by the Nessler regent, I. Prepration of the regent. Journal of the Science of Food and Agriculture 1952, 441-447.

[37]Zanjirband M, Kasra Kermanshahi R, Golbang N. Isolation of the moderately halophilic bacteria and effects of $\mathrm{pH}$ and incubation on their growth. Journal of Taxonomy and Biosystematics 2013, 1(1), 21-32.

\section{How to cite this article:}

Torbaghan M. E, Lakzian A, Astaraei A. R, Fotovat A and Besharati H. Quantitative comparison of ammonia and 3-indoleacetic acid production in halophilic, alkalophilic and haloalkalophilic bacterial isolates in soil. J. Fundam. Appl. Sci., 2016, 8(2S), 653-673. 